\title{
Investigating English-Indonesian Translation of Intransitive Phrasal Verbs in Brown's Principle of Language Learning and Teaching
}

\author{
Dedi Yulianto ${ }^{1}$, Widhiya Ninsiana ${ }^{2}$, Ahmad Subhan Roza ${ }^{3}$ \\ Institut Agama Islam Negeri (IAIN) Metro, Indonesia \\ Email: ddy45425@gmail.com ${ }^{1}$ \\ Email: tantowidi@yahoo.co.id ${ }^{2}$ \\ Email: ahmadsubhanroza@gmail.com ${ }^{3}$
}

\begin{abstract}
This research concerned with the translation of intransitive phrasal verb in Brown's Principle of Language Learning and Teaching from English into Indonesian. The type of this research was qualitative research which dealt with non-numerical data. This research was analyzed by using the techniques proposed by Cresswell. There are six steps, namely (1) preparing the data for analysis; (2) looking and reading all the data; (3) coding all the data; (4) using the coding to describe the setting; (5) making advanced description; and (6) making interpretation. The finding results show that the accuracy level and readability level in Brown's Principle of Language Learning and Teaching from English into Indonesian are fair with average score 2.2. The total of intransitive phrasal verbs is 17 with details: 2 sentences of accurate translation (12\%); 1 sentence of inaccurate translation $(6 \%) ; 14$ sentences of less accurate $(82 \%)$ while the readability level shows that there is 0 of readable translation; 15 less readable sentences $(88 \%)$; 2 sentences not readable translation $(12 \%)$.
\end{abstract}

Keywords: Phrasal Verb, Translation

\section{INTRODUCTION}

Today, it is ubiquitously seen that knowledge and information are world widely published in English (Xue \& Zuo, 2013). The information can be easily accepted by the audiences because it is translated into their native languages. As a consequence, translation skill is among one of the most obliged to acquire by foreign language learners (Fernández-Guerra, 2014; Calis \& Dikilitas, 2012).

Translation, according to Newmark (1988), is the transfer as many SL (source language) words to the TL (target language) as possible. Similarly, Hatim \& Munday (2004) stated that translation is a process of transferring text from source language into target language, conducted by a translator, or translators, in a specific socio-cultural context. Moreover, it can be said that translation is a process which is done by translator to transfer the information to other people in specific socio-cultural context.

Despite the significance of translation in fathoming the messages of a text, many English learners could not translate well due to some problems and challenges (Sandra, 2018; Khalifa, 2015); Al-Sohbani \& Muthanna, 2013). First, words may or may not have objective referents. It means there are some words that have the object in one country but not in other country. For example, the phrase "washing machine" is not available in some countries; they use "hand-operated washing", instead. Second, some languages are especially rich in homonyms. Homonym 
is two words that have same spelling and sound but have different meanings. For instance, can (kaleng) and can (bisa). Homonyms make the translation process become harder. Third, it is probable that few words have no exact counterpart in another language. For example, the Indonesian word "lusa" becomes "the day after tomorrow" in English. Lastly, bilinguals have a tendency to regard similar words in two language as identical in meaning.

There have been a growing number of prior studies focusing on specific elements of English into other languages including Indonesian. The previously studied elements, among others, are finite verbs (Silalahi, 2016), idioms (Smadi \& Alrishan, 2015), legal English (Karjo, 2015), simple sentence (Trivianti, 2017), cultural words (Hapsari \& Setyaningsih, 2013), and so forth. Moreover, some researchers has conducted studies on translation of phrasal verbs in various documents, such as in novel (Istima \& Polisda, 2016), in news (Kurniadi, 2018), and in English texts provided by teacher (Santika, Putri, \& Suastini, 2018). Some books also explain phrasal verbs comprehensively (Wyatt, 2006; Murphy, 2004). The large body of researches on specific elements of English including phrasal verbs delineates the significance of understanding and translating phrasal verbs into Indonesia.

However, the investigation on how phrasal verbs, more specifically intransitive phrasal verbs, in prominent books used in tertiary instruction are translated is considered rare. At IAIN (Institut Agama Islam Negeri/ State Islamic Institute) Metro, especially in English Education Department, the lecturers use English version's book to enhance the students' learning process. One of the books that the students have to read is Principle of Language Learning and Teaching by Brown. This book gives much information about how to learn and teach a language (Brown, 2006). Therefore, to help the students understand the book well, there is an Indonesian version of the book with the title "Prinsip Pembelajaran dan Pengajaran Bahasa" translated by Noor Cholis and Yusi Avianto Pareanom (Cholis \& Pareanom, 2008). Every word is translated into Indonesian included phrasal verbs. Even though the book is rich in information, many students found it hard to understand the content of the book. There are several reasons such as limited vocabularies; many unfamiliar words (it includes phrasal verb); and less capable of in translating English into Indonesian.

Due to scarcity of studies on intransitive phrasal verbs - a phrasal verb that does not take an object (Folse, 2015; Thonrbury, 2002) - and the importance of Brown's Principle of Language Learning and Teaching by in the instruction of English at IAIN Metro, the present study aimed at investigating the translation of the intransitive phrasal verbs taken from the book.

\section{METHOD}

The type of this research was qualitative research. Ary, et.al., (2010) stated qualitative research focuses on understanding social phenomena and providing rich verbal descriptions of settings, situations, and participants. The researchers collected and analyzed the data. Subsequently, they drew the conclusion based on the data analysis. The data which were collected and analyzed were in the form of intransitive phrasal verbs in Brown's Principle of Language Learning and Teaching.

The population of this research was the lecturers of English Department and the second-year students of English language teaching department of Institute for Islamic Studies of Metro which consist of four classes, class A, B, C, and D. The researcher 
decided to take only five lecturers and 10 students from each class. The sample used purposive sampling technique. According to Etikan, Musa, \& Alkassim (2016), purposive sampling to concentrate on people with particular characteristics who will better be able to assist with relevant research.

Furthermore, the researcher collected the data from documentation and questionnaire. The primary data was taken from the books includes intransitive phrasal verbs which are found in chapter 1 and 2 . The researchers referred to how Folse (2015) breaks down the three rules by which phrasal verb is said to be intransitive phrasal verb, namely (1) Intransitive phrasal verbs cannot have an object; (2) The best way to determine whether it is intransitive phrasal verb or not is to check in dictionary; and (3) Some phrasal verbs can be both intransitive and transitive but the meaning may be different. For example: phrasal verb makes up can be both transitive and intransitive phrasal verb.

The other primary data was the result of questionnaire was used to find out the accuracy and readability of the translation. The participants were required to complete the questionnaire by giving checklist on the paper in order to rate the accuracy and readability of the intransitive phrasal verb translation.

The following are the categories of the quality assessment from accuracy and readability aspect:

Table 1:

The Criteria of Accuracy Level

\begin{tabular}{ccl}
\hline $\begin{array}{c}\text { Accuracy } \\
\text { Level }\end{array}$ & Score & \multicolumn{1}{c}{ Criteria } \\
\hline Good & 3 & $\begin{array}{l}\text { The meaning of words, } \\
\text { terms, phrases, clauses, } \\
\text { sentences are conveyed } \\
\text { accurately and there is no } \\
\text { distortion of meaning. }\end{array}$ \\
\hline Fair & 2 & $\begin{array}{l}\text { Most of the meaning of the } \\
\text { words, terms, phrases, } \\
\text { clauses, and sentences have } \\
\text { been translated accurately. }\end{array}$ \\
\hline
\end{tabular}

\begin{tabular}{ll}
\hline & $\begin{array}{l}\text { However, there is still a } \\
\text { distortion of meaning or } \\
\text { there is a meaning which is } \\
\text { omitted that disrupt the } \\
\text { integrity of the message. }\end{array}$ \\
\hline & $\begin{array}{l}\text { Meaning of the words, } \\
\text { terms, phrases, clauses, } \\
\text { sentences are transferred } \\
\text { inaccurately into target } \\
\text { language or even deleted. }\end{array}$ \\
\hline
\end{tabular}

Accuracy Level

Categories:

Good = Accurate (average score 2,6 - 3)

Fair $=$ Less Accurate (average score 1,5 -2,5)

$\mathrm{Bad}=$ Inaccurate $($ average score $1-1.4)$

Table 2:

The Criteria of Readability Level

\begin{tabular}{ccl}
\hline $\begin{array}{c}\text { Readability } \\
\text { Level }\end{array}$ & Score & \multicolumn{1}{c}{ Criteria } \\
\hline Good & 3 & $\begin{array}{l}\text { Words, terms, phrases, } \\
\text { clauses, sentences can } \\
\text { be easily understood by } \\
\text { the reader. }\end{array}$ \\
\hline Fair & 2 & $\begin{array}{l}\text { Most of the translation } \\
\text { can be understood by } \\
\text { the reader, but there are } \\
\text { certain parts that must } \\
\text { be read more than one } \\
\text { times to understand the } \\
\text { translation. }\end{array}$ \\
\hline Bad & 1 & $\begin{array}{l}\text { The translation is } \\
\text { difficult for the reader to } \\
\text { understand. }\end{array}$ \\
\hline
\end{tabular}

Readability Level

Categories:

Good $=$ Readable (average score 2,6 - 3)

Fair $=$ Less Readable $($ average score 1,5 $-2,5)$

$\mathrm{Bad}=$ Not Readable (average score 1-1,4)

\section{RESULT AND DISCUSSION}

The researcher got the data from 5 lecturers and 40 students of IAIN Metro. All of the participants were asked to give the assessment level of translation quality. There are 5 lecturers, as participants, were given the questionnaire about the accuracy level of intransitive phrasal verb translation and 40 students of IAIN Metro were given the 
questionnaire about readability level of intransitive phrasal verb translation.

After getting all the data, the researcher calculated the average score based on the result of questionnaire. There were 17 sentences which contain intransitive phrasal verb found in chapter 1 and chapter 2 in Brown's Principle of Language Learning and Teaching. The participants were asked to give the checklist in the column based on the score given by the participants.

\section{Translation Accuracy}

The result of the questionnaire given to the five lecturers who gave the accuracy level in translating intransitive phrasal verbs translation could be seen in the figure below:

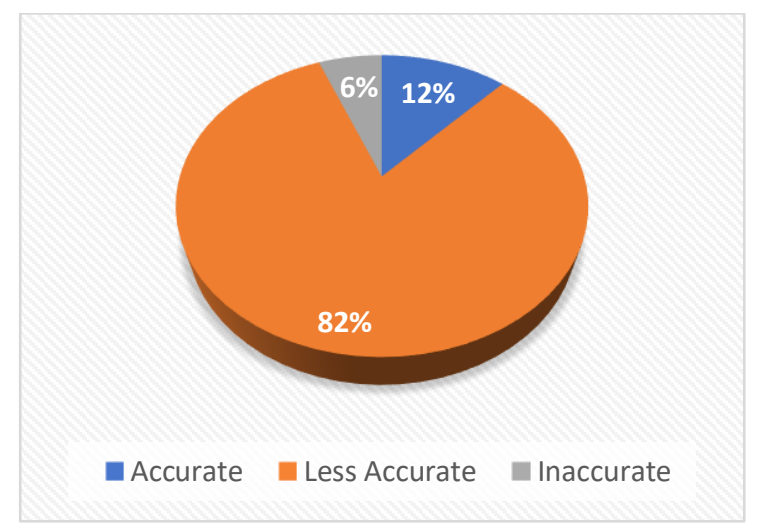

Figure1:

The Result of Questionnaire in Accuracy Aspect

The table showed that the average score for intransitive phrasal verb translation is less accurate or there were 14 sentences (82\%) with less accurate translation, 1 sentence $(6 \%)$ was inaccurate and 2 sentences (12\%) were accurate. It means that, of the total 17 sentences, all the lecturers agreed two sentences an accurate translation.

The examples of accurate accurate sentences are:

ST : What would you add to or delete from the definitions given in this chapter? Share your definitions with another classmate or in a small group. (sentence no.8)

TT: Apa yang akan anda tambahkan atau hapus dari definisi-definisi yang disajikan dalam hal ini? Sampaikan definisi-definisi anda kepada rekanrekan sekelas dan anggota-anggota kelompok kecil.

The meaning of intransitive phrasal verb given in into yang disajikan is translated correctly from English into Indonesian without the distortion of the meaning. All the raters agreed that yang disajikan is appropriate translation.

ST : Even some of the contextual categories described by - of all people - Skinner, in verbal behavior, turn out to be relevant! (sentence no.13)

TT : Bahkan beberapa teori kontekstual yang dipaparkan oleh - ironisnya Skinner, dalam verbal behavior, ternyata relevan!

The sentence no. 13 is categorized as accurate translation. Although the rater 4 gave the score 1 , the others rater gave the score 3 . Rater 1, 2, 3 and 5 found that the translation of intransitive phrasal verbs from English into Indonesia is conveyed well. The word turn out is properly translated into ternyata and they did not find any distortion of the meaning.

Then, the example of less accurate sentence is as follows

ST : There was little to distinguish Grammar Translation from what had gone on in foreign language classrooms for centuries, beyond a focus on grammatical rules as the basis for translating from the second to the native language. (sentence no.7) 
TT: Tidak banyak perbedaan antara Penerjemahan Tata Bahasa dan apa yang sudah berlangsung di kelaskelas bahasa selama berabad-abad, di luar fokusnya pada kaidah-kaidah gramatikal yang menjadi dasar penerjemahan dari bahasa kedua ke bahasa asli.

In the sentence number 7 , rater 3 and rater 4 considered intransitive phrasal verb translation is less accurate. Both the rater gave the score 2 for the translation of intransitive phrasal verb from English into Indonesia. There is still a distortion of meaning in the word gone on which is translated into berlangsung in Indonesian's version of book

The less accurate result of translation may be caused by the difficulty of finding the equivalent meaning since phrasal verbs often apply grammatical structures are often employed to create deep idiomatic sentences (McArthur \& Atkins, 1975).

Last but not least, the example of inaccurate sentences taken from the book are: ST: Some of the pieces of the language learning puzzle have been located and set in place. (sentence no.4)

TT: Beberapa kepingan puzzle pembelajaran bahasa itu sudah terkumpul dan terpasang pada tempatnya.

Rater 3 and rater 4 gave score 1 for the translation of intransitive phrasal verb in sentence number 4 . Rater 4 and rater 1 agreed that the translation of word breaking down into memilah-milah is translated inaccurately.

The translation accuracy was checked from the indicator whether whether the meaning of the source text (ST) is similar with the target text (TT) (Siregar, 2016). According to her, the accuracy of translation has objectives (1) to check the equivalence of information in a text and (2) To find another problem by comparing SL and TL. Meanwhile, Nababan, et.al., (2012) highlighted that the quality categories of accuracy in translation are (1) it can be said good if the meaning of words, terms, phrases, clauses, sentences are conveyed accurately and there is no distortion of meaning, (2) it is said fair if most of the meaning of the words, terms, phrases, clauses, and sentences have been translated accurately. However, there is still a distortion of meaning or there is a meaning which is omitted that disrupt the integrity of the message, and (3) it will be bad translation if the meaning of the words, terms, phrases, clauses, sentences are transferred inaccurately into target language or even deleted. The inaccurate translation was probably influenced by the techinques employed in translating the intransitive phrasal verbs (Aresta, 2018).

\section{The Level of Readability}

Readability is related to the level of fluency in target language. Readability deals with how natural and easy a translation is read by the reader. Siregar (2016) state that there are some criteria as follows: 1). The text can be understood easily; 2). In general, the text can be understood, but there are certain parts should be re-read to comprehend; 3 ). The text is difficult to comprehend. While According to Nababan et al., (2012), the level of readability can be seen as follows: 1) It is said to be good if words, terms, phrases, clauses, sentences can be easily understood by the reader; 2) Fair if most of the translation can be understood by the reader, but there are certain parts that must be read more than one times to understand the translation; 3) Bad if the translation is difficult for the reader to understand.

To unveil whether the Indonesian version of the intransitive phrasal verbs are 
readable or not, the questionnaires were also given to the 40 students of IAIN Metro from English Education Department. The students were given the questionnaire about the readability level of intransitive phrasal verb translation. The result could be seen in the table below:

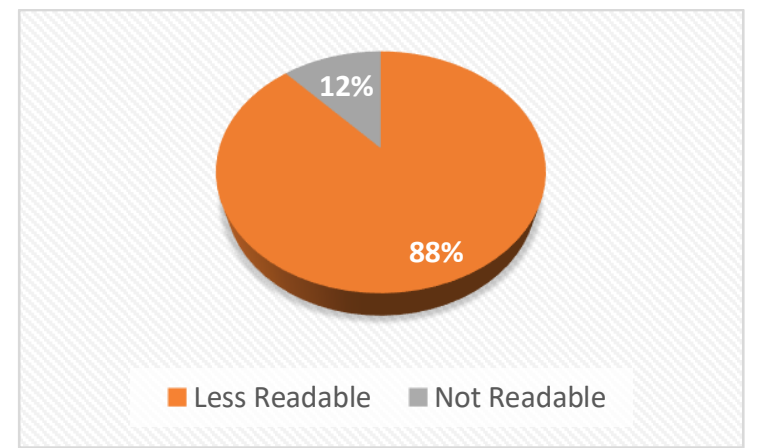

Figure 2:

The Result of Questionnaire in Readability Aspect

From 40 students of English, most of them needed to read the intransitive phrasal verb translation more than one times to understand the sentence. The table above showed that the average score for intransitive phrasal verb translation is less readable or there are 15 sentences $(88 \%)$ are less readable, and 2 sentences $(12 \%)$ are not readable and there is no readable.

\section{CONCLUSION}

In line with the result of data analysis, the discussion, it could be concluded that the accuracy level of intransitive phrasal verb translation in Principle of Language Learning and Teaching from English into Indonesian included in the categories proposed by Nababan was fair. While the readability level of intransitive phrasal verb translation in Brown's Principle of Language Learning and Teaching from English into Indonesian showed in the categories was fair. All of the conclusions above were taken from the result of questionnaire which was given to the participants.

\section{SUGGESTION}

Through this research, the researcher would like to give suggestions as follows: the accuracy level of intransitive phrasal verb translation in Principle of Language Learning and Teaching might be increased through: 1 . Before translating source language into target language, firstly, the translator needs to grasp the meaning of the source language, and then correctly render the meaning based on the structure of the target language; 2 . Look at the context of the text to improve the accuracy of translation. Translate the text as a whole not per word to get the accurate meaning of the text.

The readability level of intransitive phrasal verb translation in Principle of Language Learning and Teaching could be increased through: (1) reducing the average sentence length. When the readers read the text, the readers will focus on the sentences they read. The best average sentence length could be around 20 until 25 words per sentence. It will help the reader to remember how the sentence begins and ends; (2) cutting down the paragraph size. Most of the readers get tired after reading a long paragraph. It makes the readers need to read the text more than one times. Make sure to end the paragraph after a couple of sentences.

\section{REFERENCES}

Al-Sohbani, Y., \& Muthanna, A. (2013). Challenges of Arabic-English and English-Arabic translation: The need for re-systematic curriculum and methodological reforms in Yemen. Academic Research International, 4(4). Retrieved from www.journals.savap.org.pkwww.sava p.org.pk 
Aresta, R. (2018). The Influence of Translation Techniques on the Accuracy and Acceptability of Translated Utterances that Flout the Maxim of Quality. Jurnal Humaniora, 30(2), https://doi.org/10.22146/jh.v30i2.336 45

Ary, D., Jacobs, L. C., Razavieh, A., \& Sorensen, C. K. (2010). Introduction to Research in Education (8th Editio). Canada: Wadsworth Cengage Learning.

Brown, H. D. (2006). Principles of Language Learning and Teaching (5th Editio). MY: Pearson Education ESL.

Calis, E., \& Dikilitas, K. (2012). The Use of Translation in EFL Classes as L2 Learning Practice. Procedia - Social and Behavioral Sciences, 46, 50795084.

https://doi.org/10.1016/j.sbspro.2012. 06.389

Cholis, N., \& Pareanom, Y. A. (2008). Prinsip pembelajaran dan pengajaran bahasa. Jakarta: Kedutaan Besar Amerika Serikat.

Etikan, I., Musa, S. A., \& Alkassim, R. S. (2016). Comparison of Convenience Sampling and Purposive Sampling. American Journal of Theoretical and Applied Statistics, 5(1), 1-4. https://doi.org/10.12691/education-66-38

Fernández-Guerra, A. B. (2014). The Usefulness of Translation in Foreign Language Learning: Students' Attitudes. International Journal of English Language and Translation
Studies, 2(1), 153-170. Retrieved from http://repositori.uji.es/xmlui/handle/1 0234/134505

Folse, K. S. (2015). Clear Grammar 3, 2nd Edition: Keys to Grammar for English Language Learners (ELT, ed.). Michigan.

Hapsari, N. D., \& Setyaningsih, R. W. (2013). Cultural Words and the Translation in Twilight. Anglicist, 2(2), 75-81.

Hatim, B., \& Munday, J. (2004). Translation an Advanced Resource Book. London: Routledge.

Istima, \& Polisda, Y. (2016). Translating English Phrasal Verbs Into Indonesian Language. LINGUA LITERA: Journal of English Linguistics and Literature, 2(1), 36-56.

Karjo, C. H. (2015). Problems in Translating Legal English Text into Indonesian Bina Nusantara University, Jakarta, Indonesia. Arab World English Journal (AWEJ), 6(2), 352-364.

Khalifa, E. M. (2015). PROBLEMS IN TRANSLATING ENGLISH AND ARABIC LANGUAGES' STRUCTURE: A CASE STUDY OF EFL SAUDI STUDENTS IN SHAQRA UNIVERSITY. European Journal of English Language and Literature Studies, 3(4), 22-34.

Kurniadi, N. (2018). EFL Students Strategies in Translating English Phrasal Verbs. Konferensi Nasional Ke- 7 Asosiasi Program Pascasarjana Perguruan Tinggi Muhammadiyah Aisyiyah (APPPTMA) 299, 299-306. 
McArthur, T., \& Atkins, B. (1975). Dictionary of English Phrasal Verbs and their Idioms. Singapore: Pan Pasific.

Murphy, R. (2004). English Grammar in Use 3rd Edition. United Kingdom: Cambridge University Press.

Nababan, M., Nuraeni, A., \& Sumardiono. (2012). Pengembangan Model Penilaian Kualitas Terjemahan. Kajian Linguistik Dan Sastra, 24(1), 39-57. Retrieved from https://doi.org/10.15640/ij1l.v4n1a27

Newmark, P. (1988). A Textbook of Translation = Fan Yi Jiao Cheng. SHANGHAI: FOREIGN LANGUAGE EDUCATION PRESS.

Sandra, R. A. (2018). From English to Indonesia: Translation Problems and Strategies of EFL Student Teachers A Literature Review. International Journal of Language Teaching and Education, 2(1), 13-18. https://doi.org/10.22437/ijolte.v2i1.4 520

Santika, I. D. A. D. M., Putri, I. G. V. W., \& Suastini, N. W. (2018). Translation of phrasal verbs into Indonesian. Journal of Applied Studies in Language, 2(1), 44.

https://doi.org/10.31940/jasl.v2i1.804

Silalahi, R. (2016). Some Problems Found In Translating English Language into Indonesia Language (Translating English Verbs into Indonesian). British Journal of English Linguistics, 4(6), 23-38.
Siregar, R. (2016). Translation quality assessment of "the 8th habit: from effectiveness to ereatness by Stephen $\mathrm{R}$. covey" into Indonesian. International Journal of Language and Literature, 4(1), 228-239. https://doi.org/10.15640/ij1l.v4n1a27

Smadi, O., \& Alrishan, A. (2015). Strategies Used by Jordanian EFL University Graduate Students in Translating Idioms into Arabic. Journal of Education and Practice, 6(6), 45-55. Retrieved from http://eproxy.lib.hku.hk/login?url=htt p://search.ebscohost.com/login.aspx? direct $=$ true $\& \mathrm{db}=$ eric $\& \mathrm{AN}=\mathrm{EJ} 108367$ $0 \&$ site $=$ ehost-live $\&$ scope $=$ site

Thonrbury, S. (2002). How to Teach Vocabulary. London: Longman.

Trivianti, V. (2017). THE CLASS SHIFT OF SIMPLE SENTENCE IN ENGLISHINDONESIAN TRANSLATION OF THE THE STARS SHINE DOWN NOVEL A. STATE ISLAMIC UNIVERSITY OF SYARIF HIDAYATULLAH.

Wyatt, R. (2006). Check Your English Vocabulary for Phrasal Verbs and Idioms. London: A \& C Black Publisher Ltd.

Xue, J., \& Zuo, W. (2013). English Dominance and Its Influence on International Communication. Theory and Practice in Language Studies, $3(12)$, 2262-2266. https://doi.org/10.4304/tpls.3.12.2262 $-2266$ 